\title{
Organic Solar Cells and its Characteristics
}

\section{Gupta $A^{*}$}

Department of Physics, University of Lucknow-226007, Lucknow, India

\begin{abstract}
This paper describes the characteristics of organic solar cell. Several characteristics impact on the conversion efficiency of organic solar cells was discussed. Recently, organic solar cells are attracting a lot of attention due to flexibility, low cost, light weight and large-area applications, and significant improvement in the power conversion efficiency. But the efficiencies of organic solar cells are still lower than crystal silicon solar cells. A circuit model of the solar cell provides a quantitative estimate for losses in the solar cell to interpret the characteristics of the solar cell. However, compared with inorganic solar cells, organic solar cells are lack of a three-dimensional crystal lattice, different intramolecular and intermolecular interactions, local structural disorders, amorphous and crystalline regions, and chemical impurities. Therefore, an appropriate model is represented in the paper.
\end{abstract}

Keywords: Organic; Efficiency; Photovolatic; Charge carriers

\section{Introduction}

Solar light is the most important source of regenerative energy as waterpower, wind and biomass. The annual energy input of solar irradiation on Earth exceeds the world's yearly energy consumption by several thousand times [1]. For the conversion of solar energy, fundamentally new developments are important. Today's most promising tools to make use of solar energy are its direct conversion into electrical energy in photovoltaic cells.

All over the world, consumption of energy has increased every year by several percentages over the last fifty years [2]. Nowadays, most of energy is supplied by fossil fuels on the one hand and by nuclear energy on the other hand. However, these resources are limited and their use has a serious environmental impact, which extends probably over several future generations. The applied photovoltaic cells mainly are silicon-based solar cells in most cases. However, compared with traditional silicon-based solar cells, Organic solar cells are a promising way towards large-area and low-price, robust, user friendly photovoltaic systems. The main advantages are the easy preparation, low process, temperatures, low-cost materials and processing technology and the possibility to produce flexible devices on plastic substrates [3]. When the power conversion efficiency of organic solar cells is close to $10 \%$, it can be served as an excellent candidate. The low power conversion efficiency of organic solar cells confines its application [4]. The power conversion efficiency was only $10-5 \%$ about fifty years ago.

\section{Characteristics of Organic Cells}

Organic solar cells and inorganic solar cells are based on photovoltaic effect. There are some well-known differences between organic solar cells and inorganic solar cells [5]. Organic solar cells are lack of a three-dimensional crystal lattice, different intramolecular and intermolecular interactions, local structural disorders, amorphous and crystalline regions, and chemical impurities. Obviously, when light absorption in inorganic solar cells, it leads to the formation of more free carriers, but when light absorption in organic solar cells, it leads to the formation of more excitons. Excitons have more binding energy in organic solar cells, and the mobilities of charge carriers are far lower in organic solar cells than in inorganic solar cells (Figure 1). As one of the many consequences of this, the power conversion efficiency of organic solar cells is much less than inorganic solar cells [6].

\section{Basic Processes in Organic Solar Cells}

In general, for a successful organic photovoltaic cell five important processes have to be optimized to obtain a high conversion efficiency of solar energy into electrical energy: (1) Absorption of light and generation of excitons (2) Diffusion of excitons to an active interface (3) Charge separation (4) Charge transport (5) Charge collection.

To create a working photovoltaic cell, the two photoactive materials are sandwiched between two (metallic) electrodes (of which one is transparent), to collect the photo generated charges (Figure 2). After the charge separation process, the charge carriers have to be transported to these electrodes without recombination. Finally, it is important that the

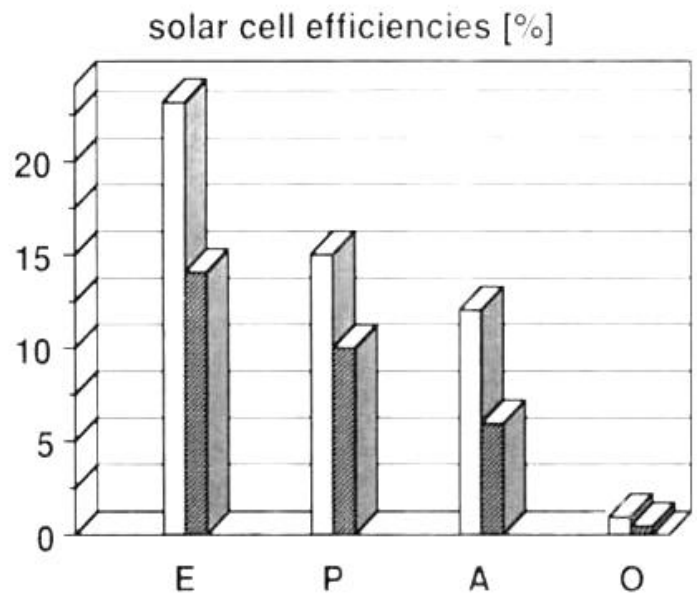

Figure 1: Power conversion efficiencies- $E$ : Single Crystalline silicon, $P$. Polycrystalline Silicon A: Amorphous silicon O: Organic solar cells.

*Corresponding author: Gupta A, Inspire Fellow, Department of Physics, University of Lucknow, Lucknow, India, Tel: 0522-2740057; E-mail: ankitguptalu2011@gmail.com

Received October 03, 2015; Accepted October 15, 2015; Published October 25 2015

Citation: Gupta A (2015) Organic Solar Cells and its Characteristics. J Material Sci Eng 4: 203. doi:10.4172/2169-0022.1000203

Copyright: (c) 2015 Gupta A. This is an open-access article distributed under the terms of the Creative Commons Attribution License, which permits unrestricted use, distribution, and reproduction in any medium, provided the original author and source are credited. 


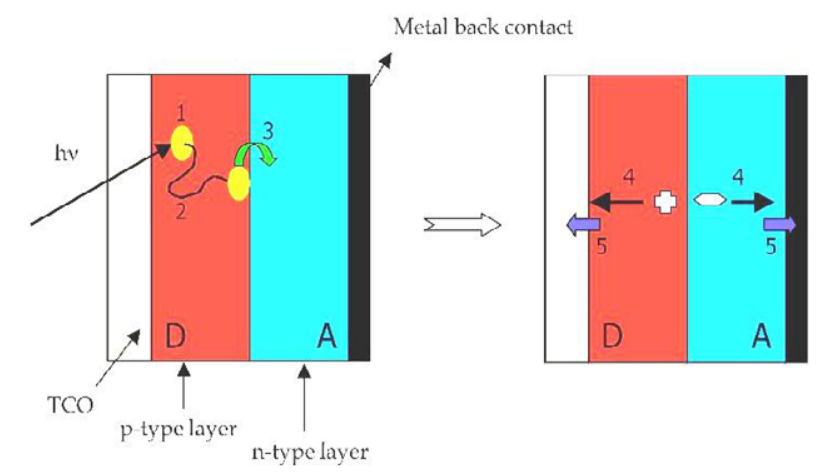

Figure 2: Working principle of an organic photovoltaic cell.

charges can enter the external circuit at the electrodes without interface problem [7].

\section{Results and Discussion}

The schematic diagram usually used to illustrate the characteristics of solar cells. It is a kind of simple understanding about characteristics of solar cells. Compared other kinds of solar cells, organic solar cells have unique properties. It considers low-level-injection conditions in short. The injection level of organic solar cells is low, which is in favour of more precise illustrating the characteristics of organic solar cells.

\section{Acknowledgments}

The authors wish to gratefully acknowledge the financial support from Department of Science and Technology (Govt. of India), New Delhi as inspire fellow (IF140869) and library facility provided by National Physical Laboratory (NPL), New Delhi.

\section{References}

1. Gregg BA (2005) The photoconversion mechanism of excitonic solar cells. MRS Bulletin 30: 20-22.

2. Brabec C (2005) Production Aspects. MRS Bulletin 30: 51.

3. Callister WD, Rethwisch DG (2012) Fundamentals of Materials Science and Engineering : An Integrated Approach. John Wiley and Sons, USA.

4. Maennig B, Drechsel J,Gebeyehu D,Simon P, Kozlowski F, et al.(2004) Organic p-i-n solar cells. Applied Physics A: Materials Science and Processing 79: $1-14$.

5. Hoffman AR (2001) Solar energy. In Macmillan encyclopedia of energy. Macmillan, New York.

6. Smith KK (2005) Solar energy. In her Powering our future: an energy sourcebook for sustainable living. New York, Universe.

7. Scheer $\mathrm{H}$ (2002) The solar economy: renewable energy for a sustainable global future. Earthscan, London, Sterling, VA. 